\section{Australian Journal of \\ Crop Science}

AJCS 14(10):1616-1622 (2020)

doi: 10.21475/ajcs.20.14.10.p2392

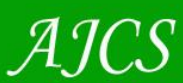

ISSN:1835-2707

\title{
Vegetative growth of 28 genotypes of Coffea canephora at 850 meters of altitude
}

\author{
Madlles Queiroz Martins ${ }^{1,2}$, Fábio Luiz Partelli ${ }^{3}$, Adelmo Golynski ${ }^{4}$, Nivaldo de Sousa Pimentel ${ }^{4}$, Adésio \\ Ferreira $^{2}$, Weverton Pereira Rorigues ${ }^{5}$, José Cochicho Ramalho ${ }^{6,7}$
}

${ }^{1}$ Programa de Pós-Graduação em Genética e Melhoramento, Centro de Ciências Agrárias e Engenharias, Universidade Federal do Espírito Santo, Alegre - ES, Brasil

${ }^{2}$ Departamento de Agronomia, Centro de Ciências Agrárias e Engenharias, Universidade Federal do Espírito Santo, Alegre - ES, Brasil

${ }^{3}$ Departmento de Ciências Agrárias e Biológicas, Centro Universitário Norte do Espírito Santo, Universidade Federal Espírito Santo, São Mateus - ES, Brasil

${ }^{4}$ Instituto Federal Goiano, Campus de Morrinhos, Rodovia BR-153, Km 633, Zona Rural. Caixa Postal 92, CEP 75650000 - Morrinhos - Goiás, Brasil

${ }^{5}$ Centro de Ciências Agrárias, Naturais e Letras, Universidade Estadual da Região Tocantina do Maranhão, Estreito, MA, 65975-000, Brasil

${ }^{6}$ Plant-Environment Interactions \& Biodiversity Lab (PlantStress\&Biodiversity), Linking Landscape, Environment, Agriculture and Food Unit (LEAF), Dept. Recursos Naturais, Ambiente e Território (DRAT), Instituto Superior de Agronomia (ISA), Universidade de Lisboa (ULisboa), Quinta do Marquês, Av. República, 2784-505 Oeiras, Portugal ${ }^{7}$ Unidade de Geobiociências, Geoengenharias e Geotecnologias (GeoBioTec), Faculdade de Ciências Tecnologia (FCT), Universidade NOVA de Lisboa (UNL), Quinta da Torre, 2829-516 Caparica, Portugal

*Corresponding author: partelli@yahoo.com.br

Abstract

Coffea canephora plants grown at low or elevated temperatures undergo changes in photosynthetic processes, which have a direct impact on vegetative growth. This species shows plants with distinct stress tolerance mechanisms and a great genetic diversity; however, there are no studies concerning the study of altitude on plant growth for these genotypes. The objective of this study was to evaluate the growth rates of orthotropic and plagiotropic branches from 28 Coffea canephora genotypes, ca. 3 years of age, cultivated at $850 \mathrm{~m}$ of altitude. The experimental design was a randomized complete block design with four repetitions. Each repetition was compounded by five plants. The period of the experimental evaluation was from 01/23/2013 to 07/07/2013. We selected and identified the orthotropic and plagiotropic branches, which were evaluated bimonthly according to their length (mm), assessing the growth rates. The results were associated with climatic factors that occurred during the experimental period. The genetic material of Coffea canephora evaluated in the study shows genetic diversity to the characteristics growth rate of orthotropic and plagiotropic branches, thus, it is possible to select genotypes with potential for cultivation at $850 \mathrm{~m}$ of altitude. In general, genotypes of Coffea canephora exhibited variations in growth rates, mainly in response to changes in temperature, with a sharp and constant drop in growth rates between the period from 05/05/2013 to 05/23/2013, when the recorded temperatures were always below $13^{\circ} \mathrm{C}$. Genotypes A1, NV2 and NV1 can be pointed as the ones which showed the best vegetative growth results at 850 meters of altitude.

Keywords: cultivar, breeding, growth rate, low temperature.

Introduction

The genus Coffea is represented by at least 124 species (Davis et al., 2011), of which C. arabica L. (arabica) and C. canephora Pierre ex A. Froehner (conilon or robusta coffee) dominate the world trade, producing about $99 \%$ of what is one of the most valuable products of the global economy, coffee. More than 150 million sacks were harvested in 2016, worldwide, where 95 million were $C$. arabica and 56 million C. canephora. The highest producers were Brazil, followed by Vietnam, Colombia, Indonesia, Ethiopia, Honduras and India (ICO, 2018). According to Van der Vossen (2016), coffee moves 175 billion dollars, and is produced by more than 25 million families.

The best vegetative growth is observed at average annual temperatures ranging from 19 to $23 \stackrel{\circ}{ }$, for $C$. arabica, and from 22 to 26 ㅇ C for C. canephora (DaMatta \& Ramalho, 2006). C. canephora shows a higher growth rate when cultivated in climates with minimum air temperatures above 17 ㅇ C (Partelli et al., 2010; 2013) and average maximum air temperature below 33 ㅇ (Covre et al., 2016; Dubberstein et al., 2017). Therefore, its cultivation in a high-altitude region 
may show development problems, due to some genotypes' limitations, mainly in the coldest months of the winter. However, the species has a high genetic diversity (Leroy et al., 2014) and may be adaptable to low temperature conditions.

The Intergovernmental Panel on Climate Change (IPCC, 2014) predicts that there will be significant changes in agroclimatic zoning, involving significant loss of areas considered suitable for coffee cultivation in important producing countries, such as Brazil and Vietnam (Bunn et al., 2015; Rodrigues et al., 2016a). Hence, C. canephora cultivation in areas with high altitude is increasing over the years, aiming at increasing productivity and grain quality, as is verified in Arabica coffee (Abreu et al., 2012; Tolessa et al., 2017).

The cerrado region in Brazil is characterized by two well defined seasons (dry and cold winter and rainy summer). The dry period varies from four to seven months and the rains are concentrated from October to March. The average temperature is around 22-27 으, with the maximum temperature averages suffering little variation, throughout the months. Nevertheless, in the winter, the temperature average variation (day/night) is above 12 o $\mathrm{C}$, and sometimes minimum temperatures of $10 \stackrel{\circ}{ } \mathrm{C}$ may happen in the colder months (Fernandes et al., 2012).

When $C$. canephora is cultivated under low temperature conditions, it develops changes in photosynthetic processes, namely a decrease in the net photosynthesis rate and lower efficiency of the photosystem II, accompanied by the reduction of stomatal conductance (Zhu et al., 2008; Partelli et al., 2009). However, conilon coffee shows high genetic diversity (Fonseca et al., 2004), with plants displaying different tolerance mechanisms at low temperatures (Partelli et al., 2009; 2011; Batista-Santos et al., 2011; Ramalho et al., 2014; Scotti-Campos et al., 2014).

When exposed to gradual applied low temperatures, $C$. canephora display defense mechanisms that may allow different acclimatization capacities, which depends on the cultivar (Ramalho et al., 2014; Ramalho et al., 2018). Recently, some researchers have been studying the cultivation of Conilon at high altitude in the State of Rio de Janeiro (Barbosa et al., 2014; Rodrigues et al., 2016b), demonstrating its potential use at higher altitudes.

Based on the knowledge of the plant adaptive mechanisms and the great genetic variability of $C$. canephora, and through a breeding program aiming at obtaining cultivars adapted to climatic conditions of high altitude, it is possible to find low temperature tolerant genotypes and/ cultivars. Hence, it is consistent to evaluate $C$. canephora genotypes in high altitude areas, as there are no studies regarding the evaluation of genotypes growth under these conditions.

Thus, our objective was to evaluate the seasonal variation of the growth rate in orthotropic and plagiotropic branches from 28 C. canephora genotypes cultivated at 850 meters of altitude, under high altitude climatic conditions with evidenced stressing low temperatures in the winter.

\section{Results and discussion}

Four groups were clustered regarding the characteristic growth rate of orthotropic branches (Figure 2A). The first and second groups were composed by nine genotypes each (Group 1: 22, 13, 25, 7, 11, 14, 20, 1, 16) and (17, 5, 8, 26, 12, $27,23,3,21)$, the third group comprised seven genotypes
$(18,2,9,19,28,4,6)$ and the fourth group three $(15,10,24)$. Four groups were also formed for growth rate of plagiotropic branches (Figure 2B), where the first was clustered with three genotypes $(25,14,17)$; the second group consisted of six $(15,24,27,19,2,9)$, the third group composed of seven $(23,4,16,3,13,1,22)$ and the fourth group composed of 12 genotypes $(12,5,6,18,20,26,28,11$, $21,8,10)$.

The groups formed by the growth rate characteristics of orthotropic and plagiotropic branches (Figure 2), are distinct when compared among each other, indicating that the groups should be evaluated separately. For the orthotropic branches, there was proximity between the third and the fourth group and the first and second group (Figure 2A), where the genotypes show values for growth rate of orthotropic branches closer than the other groups.

The degree of similarity between the groups may be evidenced by the condition the groups of genotypes assumed before the cut-off point was established. If the same groups were assumed before cutting, the group is considered similar, even if there is separation after cutting in the clustering tree. If the groups had already assumed a high degree of distance before the cut-off point was established, it is granted that these groups have independent behavior and, therefore, they are less similar when compared to the other groups.

These differences correspond to divergence degrees in terms of adaptation, which can be characterized using predictive methods, which allow to quantify the genetic variability in coffee trees. These methods are based on morphological, physiological or molecular differences between genitors, which are quantified through measures of dissimilarity (Freitas et al., 2009).

To use the genetic variability, efficient strategies are determinant for the success of coffee breeding programs (Rocha et al., 2013). According to Rodrigues et al. (2015), the formation and characterization of groups of genotypes are essential to guide the selection of genetic material in breeding programs, since it allows to establish combinations based on the degree of dissimilarity between genotypes, to explore the required potential in order to reach high agronomic performance.

For both characteristics orthotropic and plagiotropic branches, few groups were formed. In this case, the clustering analysis was important for this study, thus, the chance to select similar genotypes is high, giving smaller gains in the coffee breeding process. Cruz et al. (2004), suggest the use of individuals with different patterns of dissimilarity in breeding programs, avoiding the restriction of genetic variability and providing greater gains in selection. Relating the climatic data (Figure 1), with the results of growth rate of orthotropic and plagiotropic branches (Figures 3 and 4), we can see a directly proportional response of the growth rates to changes in temperature, especially minimum temperatures. As the minimum temperatures decrease, the growth rates of the $C$. canephora genotype groups also decrease to a greater or lesser degree depending on the group of genotypes. This behavior can be attributed to the fact that the growth rates of the orthotropic and plagiotropic branches of the coffee tree undergo seasonal variations throughout the year, and under minimum air temperatures below 17 으, the growth rate of the branches is reduced (Figures 3 and 4), as it was 
Table 1. List of the 28 C. canephora genotypes used in the experiment, in the Instituto Federal Goiano, in Morrinhos - GO.

\begin{tabular}{lccc}
\hline A & AC & A & AC \\
\hline $1 \mathrm{~V}$ & 1 & NV2 & 14 \\
$2 \mathrm{~V}$ & 2 & 14 from Emcapa 8121 & 15 \\
$3 \mathrm{~V}$ & 3 & Clone 18 & 16 \\
$4 \mathrm{~V}$ & 4 & NV1 & 17 \\
$5 \mathrm{~V}$ & 5 & NV8 & 18 \\
$6 \mathrm{~V}$ & $\mathrm{P} 1$ & 19 \\
$7 \mathrm{~V}$ & 6 & 3 from Emcapa 8121 & 20 \\
$8 \mathrm{~V}$ & 7 & $\mathrm{P} 2$ & 21 \\
$9 \mathrm{~V}$ & 8 & 4 from Bahia & 22 \\
$10 \mathrm{~V}$ & 9 & NV3 & 23 \\
$11 \mathrm{~V}$ & 10 & Verdim TA & 24 \\
$12 \mathrm{~V}$ & 11 & A1 & 25 \\
$13 \mathrm{~V}$ & 12 & Robustão Seeds & 26,27 and 28 \\
\hline
\end{tabular}

(A): Accessions; (AC): Accessions code, corresponding to 28 C. Canephora genotypes analyzed in the experiment. V1 to V2 - genotypes that compose the Vitória cultivar. A1 - composes the Tributun cultivar 3 and 14 from Emcapa - compose the Emcapa 8121cultivar.

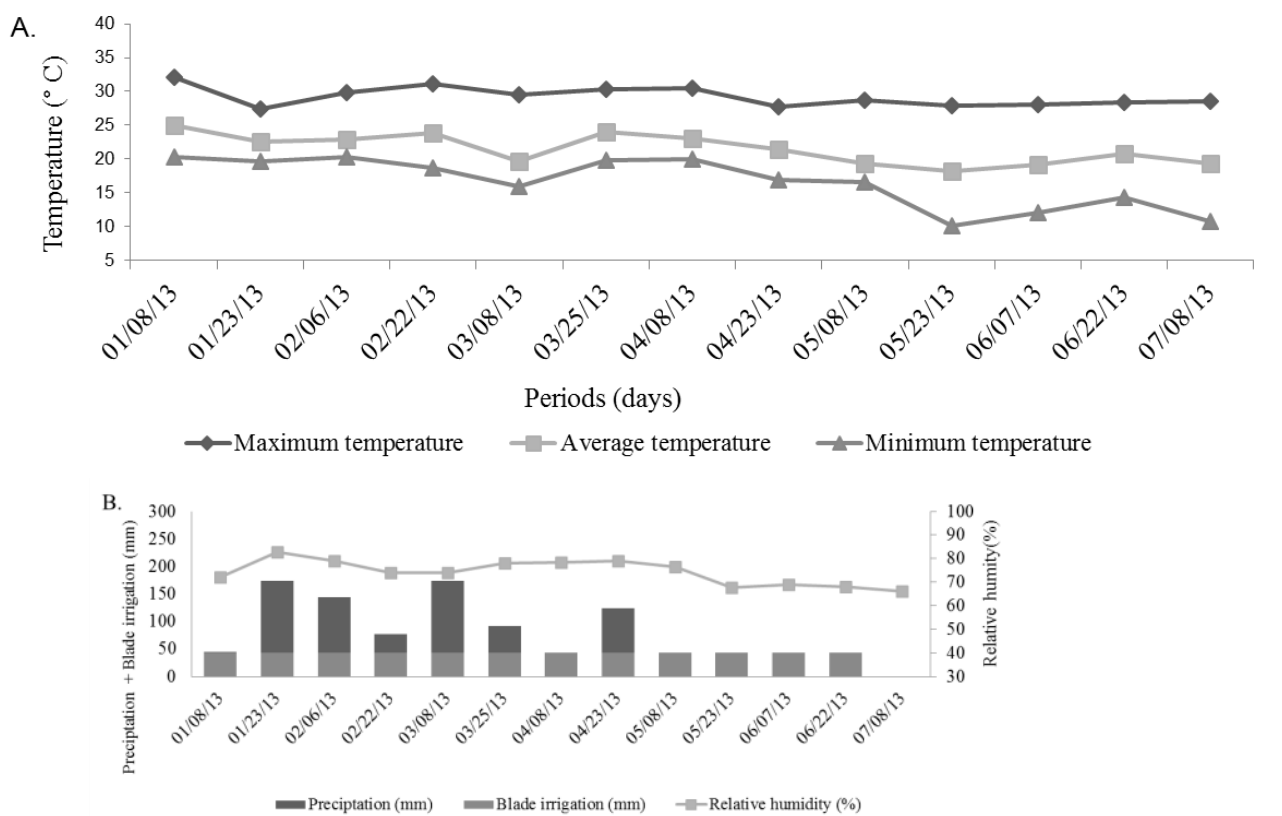

Fig 1. Maximum, average and minimum air temperature $\left({ }^{\circ} \mathrm{C}\right)(\mathrm{A}$.$) , air relative humidity (\%), precipitation (mm) and irrigation blade$ $(\mathrm{mm})($ B.) measured in a cultivation experiment of $28 \mathrm{C}$. canephora genotypes at high altitude.
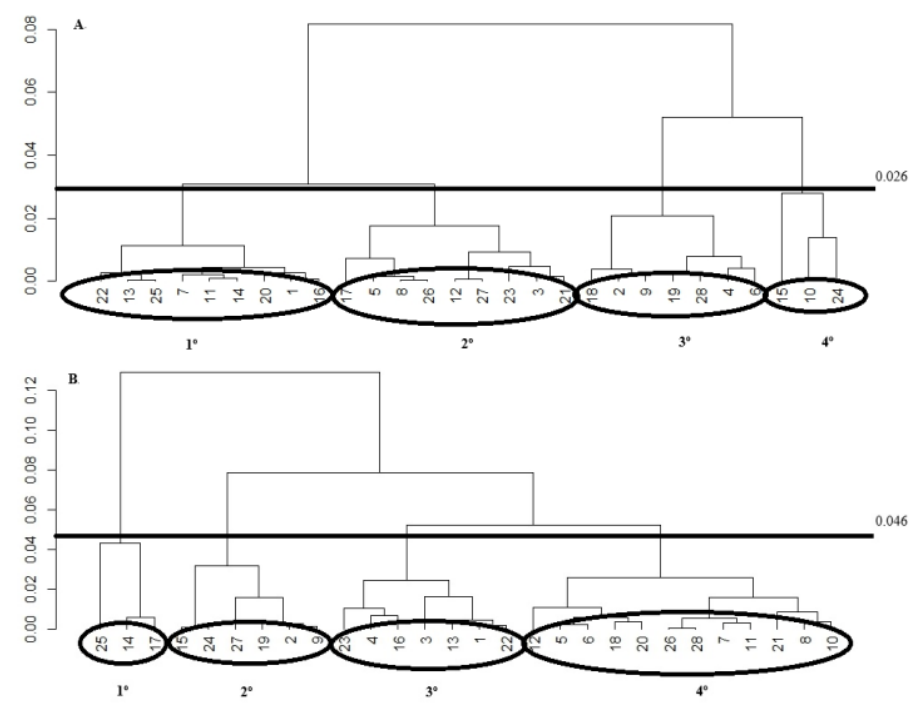

Fig 2. Dendrograms constructed for the variables growth rate of orthotropic branches (A.) and growth rate of plagiotropic branches (B.) of $28 \mathrm{C}$. canephora genotypes grown at an elevated altitude from the Euclidean distance matrix using the average linkage method (UPGMA) for the clustering. 
GROUP 1

$(22,13,25,7,11,14,20,1,16)$

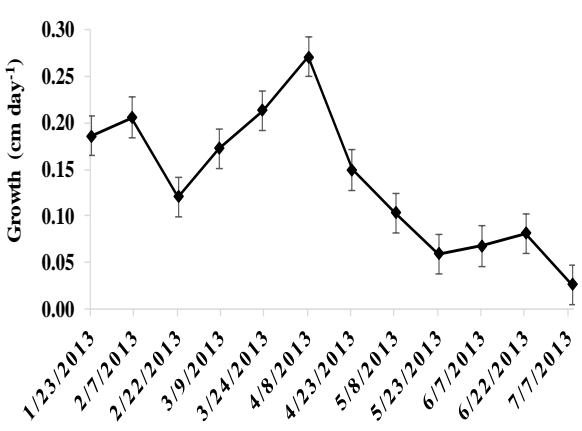

Period

$$
\text { GROUP } 3
$$

$(18,2,9,19,28,4,6)$

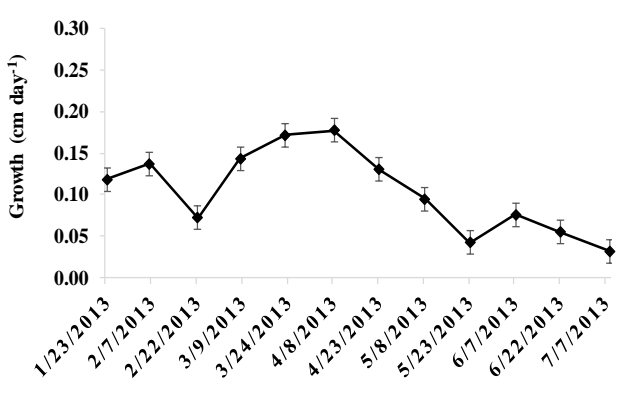

Period
GROUP 2

$(17,5,8,26,12,27,23,3,21)$

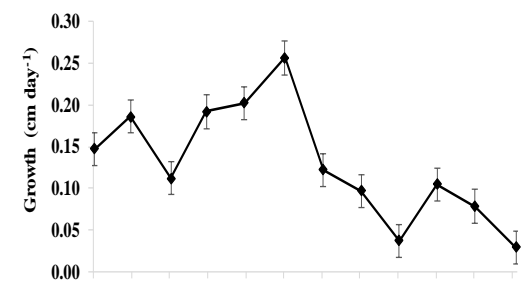

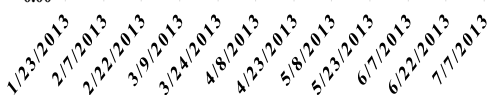

Period
$(15,10,24)$

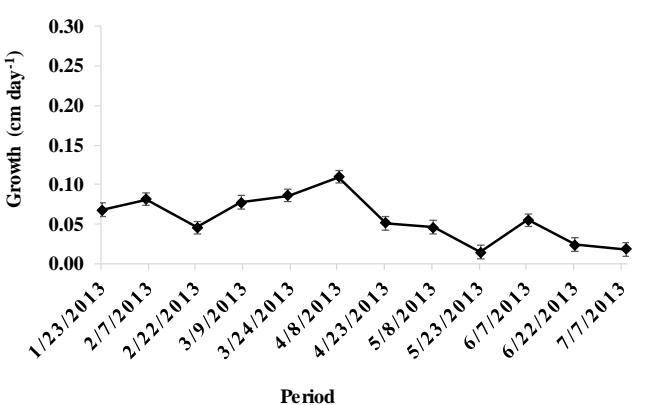

Period

Fig 3. Daily rates of vegetative growth $\left(\mathrm{mm} \mathrm{day}^{-1}\right)$ of the orthotropic branches, represented according to the accession groups involving $C$. canephora genotypes. Morrinhos, Goiás.

$$
\text { GROUP } 2
$$

$(15,24,27,19,2,9)$

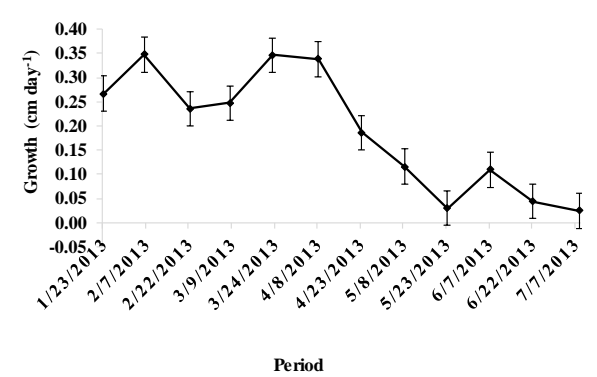

GROUP 3
$(23,4,16,3,13,1,22)$

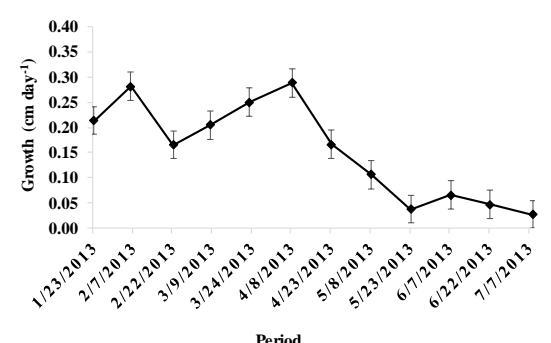

GROUP 2

$(15,24,27,19,2,9)$

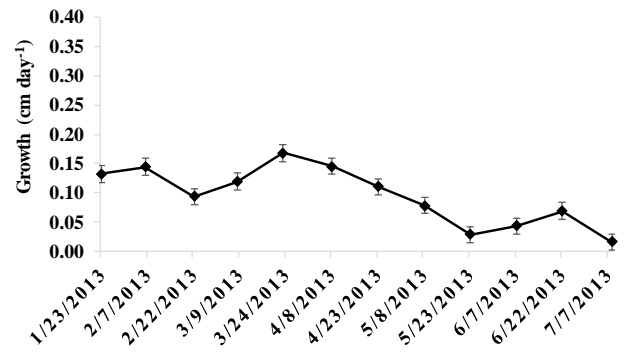

Period

\section{GROUP 4}

$(12,5,6,18,20,26,28,7,11,21,8,10)$

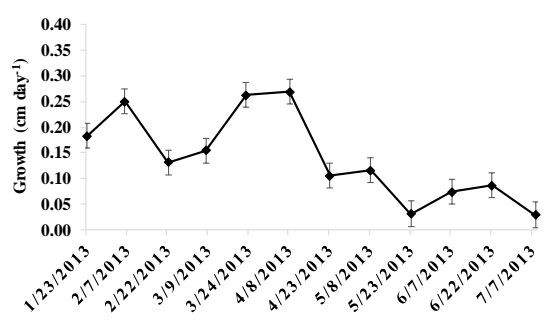

Period

Fig 4. Daily rates of the vegetative growth $\left(\mathrm{mm} \mathrm{day}^{-1}\right)$ of the plagiotropic branches, represented according to the accession groups involving $C$. canephora genotypes, grown in the south of the cerrado region in Goiás. Morrinhos, Goiás. 
found for C. canephora in other regions (Partelli et al., 2010; 2013).

The pattern of growth rate of plagiotropic and orthotropic branches evaluated in this study was similar to that reported in previous studies (Partelli et al., 2010; 2013), showing a significant decrease in growth of $C$. canephora branches when grown under minimum air temperature below 17 ㅇ․ Plants of $C$. canephora exhibit higher rates of vegetative growth in periods of long and hot days, associated with high rainfall, when compared to the vegetative growth rates observed in colder months with shorter days (Partelli et al., 2010; Covre et al., 2016). Plants of C. Canephora tolerate high temperatures (Ramalho et al., 2014; Martins et al., 2016; 2017; Rodrigues et al., 2016a; Rodrigues et al., 2018), however, are less adapted to low temperatures compared to C. arabica (DaMatta and Ramalho, 2006; Partelli et al., 2009; Batista-Santos et al., 2011; Ramalho et al., 2014; ScottiCampos et al., 2014).

The four groups in figure 3 show different growth rates according to the seasonal climatic changes during the experimental period. Group 4 showed growth always below $0.15 \mathrm{~mm} \mathrm{day}^{-1}$, regardless of the evaluated periods. Groups 1 and 2 were the least affected in the stress constrictions, in addition, they showed the highest values for growth rate of orthotropic branches in comparison to groups 3 and 4 . Partelli et al. (2013), studying the seasonal vegetative growth of $C$. canephora genotypes, in relation to climatic factors, identified a group of genotypes (V6, V7, V11, V12), which although had decreased their growth rate under temperature conditions below $17{ }^{\circ} \mathrm{C}$, have been able to maintain a steady growth, and showed a potential for tolerance to low positive temperatures.

The stress promoted by the cold, drastically affects the photosynthetic apparatus of the conilon coffee, reducing the net photosynthesis $(\mathrm{Pn})$ and fluorescence parameters (Batista-Santos et al., 2011), causing interferences in the reduction of the growth rate. These damages are driven by the overproduction of highly reactive molecules (ROS), which are usually referred as to byproducts of the redox reactions. These molecules can be formed by excitation, in this case generating singlet oxygen $\left({ }^{1} \mathrm{O}_{2}\right)$, or formed by successive additions of electrons to $\mathrm{O}_{2}$, reducing it to the superoxide radical $\left(\mathrm{O}_{2}{ }^{-}\right)$, hydroperoxyl radical $\left(\mathrm{HO}_{2}\right)$ or hydrogen peroxide $\left(\mathrm{H}_{2} \mathrm{O}_{2}\right)$ and hydroxyl radical $\left(\mathrm{OH}^{-}\right)$ (Bhattacharjee, 2010).

A decrease in the growth rate of plagiotropic branches is observed in all the groups (Figure 4), which is related to the seasonal climatic changes occurred. Regarding the growth rate of plagiotropic branches, group 2 was the most affected. Group 1 exhibited the highest growth rate values of plagiotropic branches in most of the dates evaluated in the experiment. The period of evaluation between 08.05.13 to 23.05 .13 was marked by the lowest average minimum temperature $(12 \stackrel{\circ}{ } \mathrm{C})$, and this fact promoted a greater detrimental effect on the growth rate of plagiotropic branches in all the groups. The highest values of growth rate observed for plagiotropic branches (above $0.32 \mathrm{~mm} \mathrm{day}^{-1}$ ) were obtained by the genotypes from group 102.06 .13 , 03.25.13 and 08.04.13), as what was found by Ferreira et al. (2005) in C. arabica. in the cerrado region of Goiás.

The genotypes found in group 1 (Figure 4), are included in groups 2 and 3 (Figure 3), therefore, genotypes 25, 14 and 17 (A1, NV2 and NV1) can be identified as the ones that exhibited the best vegetative growth results.
The 28 C. canephora genotypes evaluated showed differentiated growth when cultivated at 850 meters of altitude. The results may be related to the mechanisms of defense and acclimatization among the $C$. canephora genotypes evaluated. These coffee genotypes may exhibit mechanisms of adaptation to stress caused by cold, such as, loss of fluidity inherent to the decrease of lipid unsaturation and quantitative and qualitative alterations of the membrane lipids, causing the reduction of the susceptibility to lipoperoxidation preserving the cellular metabolism (Scotti-Campos et al., 2014).

Within the variability of $C$. canephora genotypes evaluated in the present study regarding their cultivation at $850 \mathrm{~m}$ of altitude, there are groups of genetic material that were able to make use of the adaptive mechanisms in a higher level, where group 1 showed better values for the conditions imposed for both the characteristics growth rate of orthotropic and plagiotropic branches, especially during the period 23.01.13 to 23.04.13, a period in which the average minimum temperature remained above $17^{\circ} \mathrm{C}$.

The higher the growth of plagiotropic branches, the higher the proportionally number of rosettes (Costa et al., 2009), allowing productivity gains (Partelli et al., 2013). Thus, some genetic material studied can be promising in terms of productivity, when grown at an altitude of 850 meters.

\section{Materials and methods}

\section{Plant material and climatic conditions}

The experiment was carried out in Morrinhos, State of Goiás, Brazil. Located at an altitude of approximately 850 meters (Latitude: 49'30" S Longitude: $49^{\circ} 12^{\prime} 01^{\prime \prime} \mathrm{W}$ ). The region of Morrinhos, is characterized by water deficit from April to October, has flat and undulating topography, with an average annual temperature of $20{ }^{\circ} \mathrm{C}$, minimum air temperature ranging from $10{ }^{\circ} \mathrm{C}$ (July) to $20^{\circ} \mathrm{C}$ (in winter), and minimum annual temperature average of $18^{\circ} \mathrm{C}$. Figure 1 shows the climatic data for the period from $23 / 01 / 2013$ to $07 / 07 / 2013$, corresponding to the experimental interval. Twenty-eight $C$. canephora genetic materials, $c a$. 3 years of age, were selected to implant the experimental crop (Table 1). The climatic data were registered by an automatic station located at approximately one $\mathrm{km}$ from the evaluated farm. The experimental cultivation consisted of 28 genotypes (Table 1), and was implanted in November 2010. The spacing used in the experimental plot was $3.5 \mathrm{~m} \times 1 \mathrm{~m}$, corresponding to the distance between the lines and between plants, respectively, and occupying $3.5 \mathrm{~m}^{2}$ per plant. The cultural treatments were carried out according to the technical guidelines for the crop, including drip irrigation.

\section{Experimental design growth traits}

The randomized block design was used, with four repetitions, each repetition composed by five plants. Measurements of the orthotropic and plagiotropic branches were taken biweekly to study the behavior of growth rates of the different $C$. canephora genotypes established in the study. To obtain the growth rate of the coffee tree, measurements of the length $(\mathrm{mm})$ of plagiotropic and orthotropic branches were made. New branches with about two pairs of fully expanded leaves were selected, where the plagiotropic branches were considered primary and 
developed from the orthotropic branch. Then, an orthotropic branch and two plagiotropic branches were randomly chosen and marked in one plant per plot. These marked branches were the targets of the periodic measures from the beginning to the end of the study. After calculating the length $(\mathrm{mm})$ of the orthotropic and plagiotropic branches, the calculation of the growth rate $\left(\mathrm{mm} \mathrm{day}^{-1}\right)$ was performed using the formula: $\mathrm{GR}=(\mathrm{FI}-\mathrm{II}) / \mathrm{nd}$, where: $\mathrm{GR}=$ growth rate; $\mathrm{FI}=$ final length; $\mathrm{II}=$ initial length and $\mathrm{nd}=$ number of days.

\section{Statistical analyses}

The data were submitted to analysis of linear regression. Afterwards, the values of regression constant and regression coefficients were obtained, and used to construct the Euclidean distance matrix, which was used as a data source for the genotypes clustering. The genotypes clustering was performed by the average linkage method (UPGMA) (Cruz et al., 2004). A cut-off point was calculated for the formation of the groups, using the constant 1.25 as suggested by Milligan \& Cooper (1985), through the formula: $(M+1.25 * s d)$, where: $M=$ mean of the values of the junction points; $s d=$ standard error of the junction point values.

After the formation of the genotype groups, we investigated the average growth rates within each formed group, both for orthotropic and plagiotropic branches. Statistical analyzes were carried out using the statistical software $R$ studio (R core team, 2016).

\section{Conclusions}

The $C$. canephora genotypes evaluated in the present study show genetic dissimilarity for the characteristics of growth rate of orthotropic and plagiotropic branches, with potential to be cultivated at $850 \mathrm{~m}$ of altitude. The $28 \mathrm{C}$. canephora genetic materials were separated in four groups for growth rate of orthotropic and plagiotropic branches. Genotypes A1, NV2 and NV1 can be identified as the ones that showed the best vegetative growth results at $850 \mathrm{~m}$ of altitude.

\section{Acknowledgements}

To the Universidade Federal do Espírito Santo - UFES and Instituto Federal de Educação, Ciência e Tecnologia Goiano IG Goiano for funding this investigation and for providing experimental resources; the Fundação de Amparo à Pesquisa e Inovação do Espírito Santo - FAPES; the Coordenação de Aperfeiçoamento de Pessoal de Nível Superior - CAPES (Finance Code 001); the Instituto Capixaba de Pesquisa, Assistência Técnica e Extensão Rural - Incaper; the Conselho Nacional de Desenvolvimento Científico e Tecnológico - CNPq. Funding from Fundação para a Ciência e a Tecnologia through the units UID/AGR/04129/2013 (LEAF) and UID/GEO/04035/2013 (GeoBioTec).

\section{References}

Abreu HMC, Nobile PM, Shimizu MM, Yamamoto PY, Silva EA, Colombo CA, Mazzafera P (2012) Influence of air temperature on proteinase activity and beverage quality in Coffea arabica. Braz J Bot. 35:357-376.
Batista-Santos $P$, Lidon $F C$, Fortunato $A$, Leitão $A E$, Lopes $E$, Partelli FL, Ribeiro Al, Ramalho JC (2011) The impact of cold on photosynthesis in genotypes of Coffea spp. photosystem sensitivity photoprotective mechanisms and gene expression. J Plant Physiol. 168(8):792-806.

Barbosa DHGS, Rodrigues WP, Vieira HD, Partelli FL, Viana AP (2014) Adaptability and stability of conilon coffee in areas of high altitud. Gen Mol Res. 13(3):7879-7888.

Bhattacharjee S (2010) Sites of generation and physicochemical basis of formation of reactive oxygen species in plant cell. In: Gupta SD (ed) Reactive oxygen species and antioxidants in higher plants. CRC press, Florida.

Bunn C, Laderach P, Rivera OO, Kirschke D (2015) A bitter cup: climate change profile of global production of Arabica and Robusta coffee. Climate Change. 129 (1-2):89-101.

Costa NR, Domingues MCS, Rodrigues JD, Teixeira Filho MCM (2009) Desempenho do cafeeiro Icatu vermelho sob ação de biorregulador aplicado em fases reprodutivas da cultura. Agrarian. 2(5):113-130.

Covre AM, Partelli FL, Bonomo R, Braun H, Ronchi CP (2016) Vegetative growth of Conilon coffee plants under two water conditions in the Atlantic region of Bahia State Brazil. Acta Sci Agron. 8(4):535-545.

Cruz CD, Regazzi AJ, Carneiro PCS (2004) Modelos biométricos aplicados ao melhoramento genético. 3.ed. Viçosa MG: UFV.

DaMatta FM, Ramalho JDC (2006) Impacts of drought and temperature stress on coffee physiology and production: A review. Braz J Plant Physiol. 18(1):55-81.

Davis AP, Gole TW, Baena S, Moat J (2012) The impact of climate change on indigenous arabica coffee (Coffea arabica): predicting future trends and identifying priorities. Plos One. 7(11):e47981.

Dubberstein D, Partelli FL, Dias JRM, Espindula MC (2017) Influência da adubação no crescimento vegetativo de cafeeiros na Amazônia sul ocidental. Coffee Science. 12(2):50-59.

Fernandes ALT, Partelli FL, Bonomo R, Golynski A (2012) A moderna cafeicultura dos cerrados brasileiros. Pesqu Agropec Trop. 42(2):231-240.

Ferreira $A$, Cecon PR, Cruz CD, Ferrão RG, Silva MF, Fonseca AFA, Ferrão MAG (2005) Seleção simultânea de Coffea canephora por meio da combinação de análise de fatores e índices de seleção. Pesqu Agropec Bras. 40:1189-1195.

Fonseca AFA, Ferrão MAG, Ferrão RG, Verdin Filho AC, Volpi OS, Zucateli F (2004) Conilon Vitória-Incaper 8142": improved Coffea canephora var. kouillou clone cultivar for the state of Espírito Santo. Crop Breed Appl Biotech. 1(4):503-505.

Freitas RG, De Vasconcelos ES, Cruz CD, Rosado AM, Rocha RB, Takami LK (2009) Prediction of genetic gains in open pollinated progenies of Eucalyptus urograndis cultivated in different environments and submitted to different selection procedures. Rev Arv. 33(2):255-263.

ICO (International Coffee Organization). Trade statistics. Available at: http://www.ico.org/prices/m1.htm. Accessed at June 13, 2017.

IPCC. Intergovernmental panel on climate change. Working group III. Mitigation of Climate Change. 99.p. Available at: http://report.mitigation2014.org/drafts/final-draftpostplenary/ipcc_wg3_ar5_finaldraft_postplenary_technical-summary.pdf. 2014. Accessed at June 14, 2016.

Leroy $T$, De Bellis $F$, Legnate $H$, Musoli $P$, Kalonji $A$, Loor Solórzano RG, Cubry P (2014) Developing core collections to 
optimize the management and the exploitation of diversity of the coffee Coffea canephora. Genetica. 142:185-199.

Milligan GW, Cooper MC (1985) An examination of procedures for determining the number of cluster in data set. Psychometrika. 50:159-179.

Partelli FL, Batista-Santos P, Scotti-Campos P, Pais IP, Quartin VL, Vieira HD, Ramalho JC (2011) Characterization of the main lipid components of chloroplast membranes and cold induced changes in Coffea spp. Environ Exp Bot. 74(1):194204.

Partelli FL, Marré WB, Falqueto AR, Vieira HD, Cavatte PC (2013) Seasonal vegetative growth in genotypes of Coffea canephora as related to climatic factors. J Agr Sci. 5:108-116.

Partelli FL, Vieira HD, Silva MG, Ramalho JC (2010) Seasonal vegetative growth of different age branches of Conilon coffee tree. Semina: Cienc Agr. 31(3):619-626.

Partelli FL, Vieira HD, Viana AP, Batista-Santos P, Rodrigues APD, Leitão AE, Ramalho JC (2009) Low temperature impact on photosynthetic parameters of coffee genotypes. Pesquisa Agropecuária Brasileira. 44(11):1404-1415.

R Core Team (2016) R: A language and environment for statistical computing. R Foundation for Statistical Computing Vienna Austria. URL https://www.R-project.org/.

Ramalho JC, DaMatta FM, Rodrigues AP, Scotti-Campos P, Pais I, Batista-Santos P, Partelli FL, Ribeiro A, Lidon FC, Leitão AE (2014) Cold impact and acclimation response of Coffea spp. plants. Theor Exp Plant Physiol. 26(1):5-18.

Ramalho JC, Rodrigues AP, Lidon FC, Marques LMC, Leitão $E$, Fortunato AS, Pais IP, Silva MJ, Scotti-Campos P, Lopes A, Reboredo FH, Ribeiro-Barros A (2018) Stress cross-response of the antioxidative system promoted by superimposed drought and cold conditions in Coffea spp. Plos One. 13(6):130.

Rocha RB, Vieira DDS, Ramalho AR, Teixeira AL (2013) Caracterização e uso da variabilidade genética de banco ativo de germoplasma de Coffea canephora pierre ex froehner. Coffee Science. 8(4):478-485.

Rodrigues WN, Tomaz MA, Ferrão MAG, Ferrão RG, Fonseca AFA (2015) Diversity among genotypes of conilon coffee selected in Espírito Santo state. Bioscience J. 31(6):16431650.

Rodrigues WP, Martins $M Q$, Fortunato $A S$, Rodrigues $A P$, Semedo JN, Simões-Costa MC, Pais IP, Leitão AE, Colwell F, Goulao L, Máguas C, Partelli FL, Campostrini E, ScottiCampos P, Ribeiro-Barros Al, Lidon FC, DaMatta FM, Ramalho JC (2016a) Long-term elevated air $\left[\mathrm{CO}_{2}\right]$ strengthens photosynthetic functioning and mitigates the impact of supra-optimal temperatures in tropical Coffea arabica and $C$. canephora species. Global Change Biol. 22(1):415-431 2016a.

Rodrigues WP, Vieira HD, Teodoro PE, Partelli FL, Barbosa DHSG (2016b) Assessment of genetic divergence among coffee genotypes by Ward-MLM procedure in association with mixed models. Gen Mol Res. 15(2):1-7 2016b.

Rodrigues WP, Silva JR, Ferreira LS, Machado Filho JA, Figueiredo FAMMA, Ferraz TM, Bernado WP, Bezerra LBS, Abreu DP, Cespom L, Ramalho JC, Campostrini E (2018) Stomatal and photochemical limitations of photosynthesis in coffee (Coffea spp.) plants subjected to elevated temperatures. Crop Past Sci. 69:317-325.

Scotti-Campos P, Pais IP, Partelli FL, Batista-Santos P, Ramalho JC (2014) Phospholipids profile in chloroplasts of Coffea spp. genotypes differing in cold acclimation ability. J Plant Physiol. 171:243-248.

Tolessa K, D'heer J, Duchateaub L, Boeckx P (2017) Influence of growing altitude shade and harvest period on quality and biochemical composition of Ethiopian specialty coffee. J Sci Food Agric. 97:2849-2857.

Van Der Vossen H (2016) Narrowing the yield gap of smallholder coffee production as sustainable strategy to meet rising demand for quality coffees. The 26th International Conference on Coffee Science. Kunming - China 2016 p. 2.

Zhu SQ, Zhao H, Liang JS, Ji BH, Jiao DM (2008) Relationships between phosphatidylglycerol molecular species of thylakoid membrane lipids and sensitivities to chilling-induced photoinhibition in rice. J Integr Plant Biol. 50:194-202. 